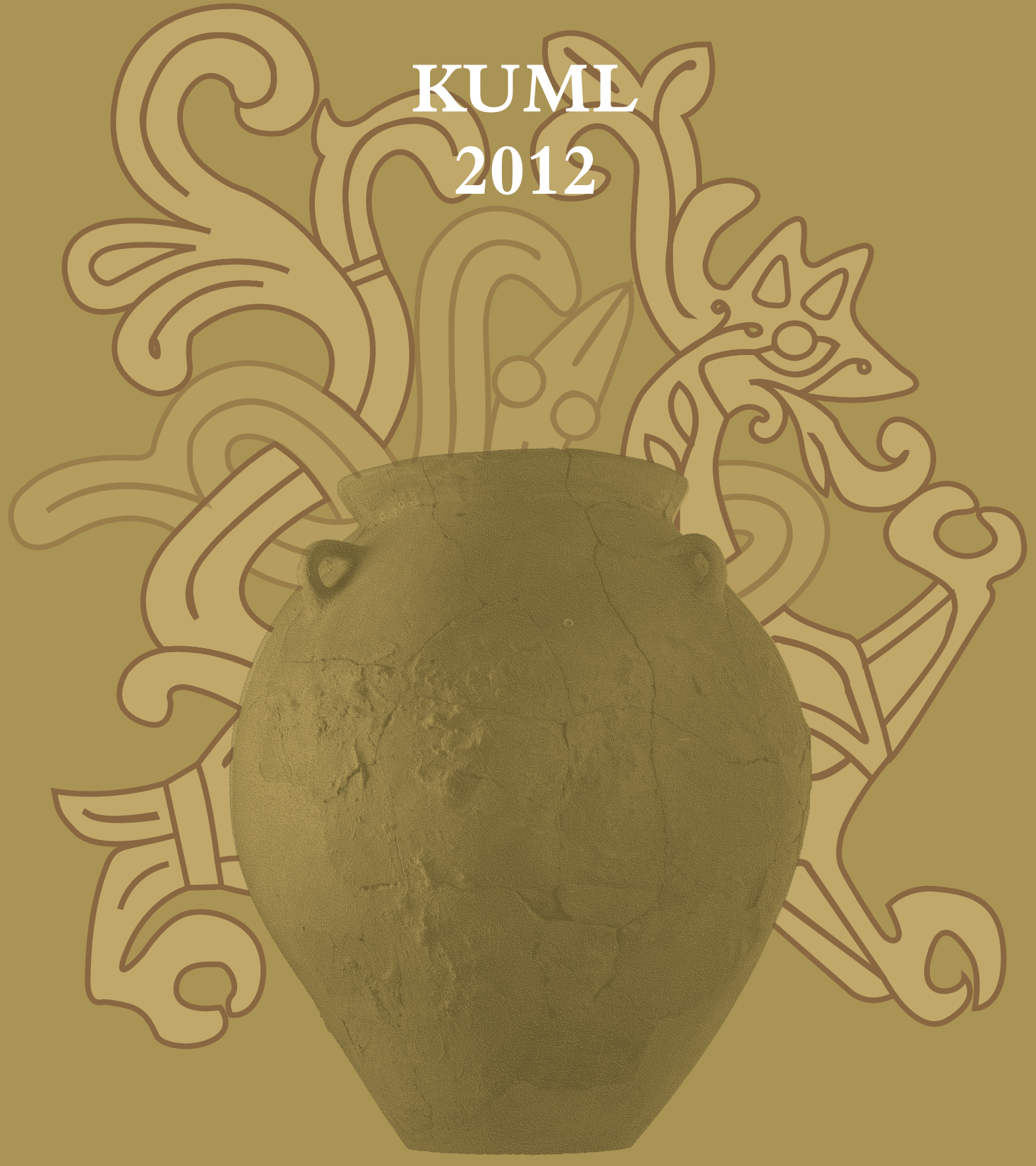




\section{KUML 2012}

Årbog for Jysk Arkæologisk Selskab

With summaries in English

I kommission hos Aarhus Universitetsforlag 


\title{
Krig og rigsdannelse
}

\author{
Af ULF NÄSMAN
}

I Kuml 2011 anmeldte jeg Andreas Raus store værk om de nye fund af hærudstyr i Nydam Mose. I samme bind findes desuden en anmeldelse af en anden publikation af hærudstyr, nemlig "Kragehul mose. Ein Kriegsbeuteopfer aus Südwestfünen" af Rasmus Birch Iversen (RBI), der blev anmeldt af Mads Ravn. Bogen om Kragehul-fundene er resultat af et projekt med det noget misvisende danske navn "Jernalderen i Nordeuropa"; den tyske titel "Kaiserzeit in Nordeuropa" er ikke meget bedre, da serien kun beskæftiger sig med én arkæologisk kildekategori, nemlig rituelle våbendeponeringer, især de såkaldte krigsbytteofferfund, som desuden kronologisk går ind i folkevandringstiden og kun findes i den begrænsede del af Nordeuropa, som strækker sig fra det sydlige Jylland til Mellemsverige.

Selve fundmaterialet fra Kragehul er velkendt. Det var derfor med en forventning om at finde nye analyser og resultater, at jeg åbnede bogen. Arkæologiens kildemateriale er normalt meget fragmenteret, og det er særlig åbenbart med Kragehul-fundet. Tolkningsmulighederne er derfor så mange, at det er få arkæologiske "sandheder", som vil kunne modstå tidens tand. Desuden kan forskellige analysemetoder bruges til bearbejdningen af samme kildemateriale, hvilket ofte vil resultere i mere eller mindre forskellige resultater. Valget af metode og kildemateriale er afhængigt af de problemer, man ønsker at finde en løsning på. Og hvilke problemer, man finder interessante, vil bero på den enkeltes teoretiske ballast. Det er derfor altid velkomment med alternative fortolkninger, fordi det kun er gennem, at forskellige tolkningsmuligheder brydes mod hinanden, at forskningen kan gå fremad. Desværre indfriedes forventningerne ikke.

Forfatteren har, vel sammen med projektets ledelse, fravalgt det lokale/regionale perspektiv på det landskab, i hvilket mennesker gentagne gange har valgt netop Kragehul Mose som det sted, hvor våben og hærudstyr deponeredes rituelt. Det perspektiv kunne have bragt nyt ind i forskningen, hvis man havde brugt plads på en landskabsarkæologisk analyse af den lokale og regionale sammenhæng. Fundpladsen burde studeres som en rituel scene og regionen vurderes ud fra militærstrategiske overvejelser i et både konkret og mentalt 
landskab. ${ }^{1}$ Den mulighed er nu forspildt. I stedet for bruges fundstedet lidt umotiveret som anledning til en diskussion om rigsdannelse m.m. Men det er selvfølgelig et emne, som fortjener at blive taget alvorligt, hvilket jeg gør i dette indlæg.

I bogen præsenteres genstandene fra et af de mindre fund, der tilhører den både velkendte og velundersøgte sydskandinaviske fundkategori, som sædvanligvis benævnes "våbenofferfund", så det overrasker ikke, at analyserne har fokus på typologi, kronologi og proveniens, d.v.s. en bearbejdning i følge "Illerup-traditionen". RBI fastholder den "danske" fortolkning af fundene som takoffer til guderne efter en sejr over en indtrængende fjende. Han tilbageviser således de forslag til omfortolkning af hærudstyrsfundene, som er fremført de senere år. Men her savnes et debatindlæg af Frands Herschend, som med gode argumenter har påpeget, at begrebet "krigsbytteoffer" (Kriegsbeuteopfer) er misvisende. ${ }^{2}$ Det var ikke krigsbyttet, som ofredes, men en hærs udstyr, "den del av den materielle kulturen som är märkt av och i sig själv är en del av begreppet "krig"." RBI er faktisk enig i denne opfattelse (s. 138), men det giver sig bare ikke entydigt udtryk i hans terminologi, hvor begrebet Kriegsbeute stadig bruges ved siden af "Opferungen von Heerausrüstungen und Waffen".

Vigtigt for RBIs ræsonnement er, at han tolker Kragehul-fundet som ofringer, der repræsenterer våben fra små troppestyrker på plyndringstogt. Ravns anmeldelse fokuserer netop på RBIs opfattelse af krig i perioden 200-500 e.Kr., og Ravn mener, at RBI derved underminerer den beskrivelse af processen, der førte til rigsdannelsen, som senest blev fremlagt i Kuml 2006. ${ }^{3}$

RBI inddeler jernalderens våbendepositioner i otte forskellige typer af fundkontekster (s. 142-144). Desværre savnes der definitioner, hvorfor det er umuligt at danne sig en begrundet mening om relevansen af dem. Til udbredelseskortet (Abb. 47) foreligger der ikke en fortegnelse, som viser, hvilke pladser på kortet som er klassificeret hvordan; man må selv gætte sig frem. De brugte kategorier af våbendeponeringer er følgende:

1) store ofringer af hærudstyr

2) små ofringer af hærudstyr

3) mono- og stereotype mosefund

4) mono- og stereotype flod- og bækfund

5) evt. ofringer af hærudstyr

6) baltiske våbendeponeringer

7) bopladsofferfund

8) depotfund. 
Som man ser, er det ikke fundtyper, der baseres på en logisk sekvens af kriterier. Den stringens, som karakteriserer den typokronologiske behandling af fundets våben, er her fraværende. At våbengrave udelukkes fra listen er rimeligt, da krig er i fokus, og våben i grave sandsynligvis primært repræsenterer noget andet end krig;,4 man kunne tillægge, at også andre af fundtyperne kan have en anden primær baggrund end netop krig. Hvordan fund klassificeret med begrebet "depotfund"(8), adskiller sig fra de andre våbendeponeringer, er uklart. Det er heller ikke klart, hvorfor monotype mosefundne våben medtages, medens monotype tørbundsfund ikke er medtaget. Hvad er forskellen på monotype og stereotype våbenfund? Hvorfor tilhører et enkelt sværd samme kategori som et fund med tyve lansehoveder? Det fremgår heller ikke, hvordan man adskiller "løse" våben på bopladser fra bopladsofferfund (7).

Det lille og meget problematiske fund fra Kragehul betragtes som en af de "små ofringer af hærudstyr," en kildekritisk usikker kategori. Kildekritisk er det meget vanskeligt at forstå, hvordan man kan udelukke, at det Engelhardt fandt, ikke bare udgør en lille del af et engang meget større fund. På ældre kort ser man tydeligt, at Kragehul Mose ligger i et landskab tæt dækket af moser, hvorfor det er vanskeligt at udelukke, at der kan findes flere deponeringer med hærudstyr i nærområdet som i Illerup Ådal eller Finnestorp. RBI mener, at Kragehul og andre mindre fund afspejler aktiviteter af små militære enheder, og at disse har spillet en anden rolle på periodens krigsscene end de store hære. Springet fra de typokronologiske analyser til "store" spørgsmål om jernalderens krig og rigsdannelse virker ikke indlysende begrundet, og da vores kendskab til fundets oprindelige omfang og karakter er så lille, er det begrænset, hvad Kragehul-fundet egentlig kan bidrage med.

Nogle af de "små ofringer af hærudstyr" antages at spejle interne jysk/fynske kampe (s. 151), medens sådanne interne kampe ikke kan belægges i de store ofringer. Imidlertid har Rau vist, at de store hærudstyrsofringer i Nydam Mose vidner om konflikter på regionalt sydskandinavisk niveau. ${ }^{5} \mathrm{Jeg}$ tror selv, at hovedparten af krigene i romersk jernalder og folkevandringstid indenfor det sydskandinaviske kulturområde blev ført mellem naboer ("Auseinandersetzungen zwischen politischen Einheiten..., die in unmittelbaren Nachbarschaft lebten"). ${ }^{6}$ Uanset om fundene tolkes som resultat af krig eller plyndringstogter, kan de betragtes som spor af en intens kamp om magt og indflydelse mellem forskellige stammer (politiske enheder eller peer polities). Den krigeriske del af peer polity interaction, se nedenfor, resulterede over tid i, at større og stærkere politiske enheder opstod.

Den fremstilling af krigs rolle i danernes rigsdannelse, som præsenteres i bogen (s. 152-157), baseres således på opfattelsen, at våbendepositionerne i 
Kragehul og flere andre hærudstyrsfund repræsenterer små troppestyrker, og at plyndring var hensigten, d.v.s et økonomisk motiv, men ikke et politisk (s. 144-147). Men der findes tolkningsmuligheder, som ikke nævnes. For lettere at finde mad til tropperne og samtidigt mere effektivt afsøge et større område for plyndringsgods splittedes barbariske hære ofte op i mindre enheder. ${ }^{7}$ Derfor er det muligt, at nogle af de små fund repræsenterer nedkæmpelse af sådanne omstrejfende tropper fra en større hær. At større samtidige nedlæggelser mangler beror måske på, at resten af hæren drog videre ubesejret. En anden mulighed kan belyses med det lille fund af hærudstyr fra Villestofte på Fyn, som kan forklares med, at en enkelt rytter er gået ned i sumpmarken ved Stavids Å, måske på flugt fra en slagmark nær Vimose, hvor et samtidigt stort fund af hærudstyr findes. ${ }^{8}$

Da RBIs referat af den model for danernes rigsdannelse, som jeg publicerede i Kuml 2006, er misvisende, og da hans synspunkter hviler på grove misforståelser, mener jeg, at læserne af Kuml fortjener en berigtigelse. Indledningsvis kritiserer RBI begrebet Pax Danorum (danernes fred), men henviser til et senere arbejde (på engelsk) end det, hvor begrebet lanceredes mere udførligt (på svensk), ${ }^{9}$ og som han åbenbart ikke har læst. Vil man forstå begrebet, og hvad det dækker, må man først læse et beskedent lille skrift af den engelske historiker Ian Wood, ${ }^{10}$ som RBI ikke nævner og måske heller ikke har læst. Wood argumenterer for, at den økonomiske blomstring rundt om Nordsøen i det 6. og 7. århundrede sikredes af merovingernes politiske og militære hegemoni. At Nordsø-området ikke destabiliseredes igen under den merovingiske nedgangstid i det 8 . århundrede har Wood svært ved at forstå, men han forsøger at forklare det med muligheden for "a temporary emergence of a strong Danish kingdom of Denmark" og "a strong and peaceable Denmark".

Woods forslag passede i store dele sammen med et diagram over antallet af "krigsindikatorer" under jernalderen i Sydskandinavien, der viste meget få krigsindikatorer i perioden fra det 6. til det 9. århundrede. ${ }^{11}$ Woods idé virkede derfor ret rimelig, men en reservation var på sin plads: "månntro [perioden] verkligen var fredlig?". Vidnesbyrd om krig findes nemlig, f.eks. tydelige krigsindikationer som anlæggelsen af det ældste Danevirke i det 7. århundrede, forsvarsværkets udbygning i år 737, samt anlæggelsen af Kanhave Kanal i år 726. Men de enkelte våben fra yngre germansk jernalder, der er fundet på våd bund, som RBI omtaler som indicier på krig, behøver ikke være deponeret i forbindelse med krig, hvorfor de på linje med våbengrave ikke har egentlig værdi som "krigsindikatorer".

Slutninger $e$ silentio er altid farlige, hvilket både Wood og jeg selvfølgelig er os bevidste, og manglen på "krigsindikatorer" er måske kun et udtryk for, at 
kildematerialet svigter. Alligevel mener jeg, at der kan ligge noget i Woods idé, nemlig at det 7. -8. århundrede kan ses som en konsolideringsfase, hvor et dansk kongerige in spe kunne befæste sit hegemoni i Sydskandinavien. Det var en fase med væsentligt færre krige, som ligger mellem en ældre fase med mange stammekrige, som er vel belagt med "krigsindikatorer", herunder især hærudstyrsofringer, og en yngre fase $\mathrm{i}$ vikingetid med andre krigsindikatorer, der snarere synliggør et kongeriges forsvar af kongemagt, befolkning og territorium.

Også Anne Nørgård Jørgensen mener, at tiden omkring 600 e.Kr. kan beskrives som en "war-free period" med "a temporary lull in warfare". ${ }^{12}$ Hun forklarer manglen på våbengrave i store dele af Sydskandinavien med en tiltagende samfundsmæssig centralisering, som kulminerede med tilsynekomsten af et første dansk kongedynasti med kong Ongendus i begyndelsen af 700-tallet. Dette er en opfattelse, som ligger nær min beskrivelse af udviklingen.

Begrebet Pax Danorum refererer ironisk til det af Edward Gibbon møntede begreb Pax Romana (den romerske fred); omtrent som et begreb Imperium Zealandium (det sjællandske imperium) ${ }^{13}$ ville forholde sig til Imperium Romanum (det romerske imperium). Det er nok for meget forlangt, at læsere med nutidens manglende kendskab til latin skulle notere, at jeg ikke brugte begrebet Pax Danica (den danske fred) men Pax Danorum (danernes fred). ${ }^{14}$ Forskellen er vigtig og markerer, at det ikke drejer sig om en fred garanteret af en stat (som i Pax Romana), men om en fred baseret på en militær, politisk og økonomisk hegemoni udøvet af et kollektiv ledet af en Rex Danorum (danernes konge), en titel der er belagt allerede tidligt i det 6 . århundrede. ${ }^{15}$

RBIs beskrivelse (s. 153-154) af, hvordan Colin Renfrews begreb peer polity interaction er brugt i diskussionen om danernes rigsdannelse, er utilfredsstillende, for ikke at sige misvisende. Læseren anbefales derfor at læse de to artikler, der henvises til. ${ }^{16}$ Begrebet har stor værdi for forståelsen af de processer, som formede de skandinaviske stammesamfund, og som drev udviklingen mod rigsdannelser. ${ }^{17}$

RBI synes at forestille sig, at the peer polity interaction foregik mellem de sydskandinaviske stammer og frankerne, en misforståelse der er så stor, at jeg undrer, om han har forstået begrebet i det hele taget. Hans udtryk "dem fränkischen peer” (s. 153 t.h.) er således helt forkert i denne forbindelse. Selvfølgelig er jeg helt enig med ham i, at de stammesamfund, som fandtes i Sydskandinavien, slet ikke kunne måle sig med de frankiske kongeriger, de var slet ikke peers. Når en Rex Danorum (danernes konge), som den frankiske kilde benævner Chochilaicus, forsøgte sig og rettede et angreb mod provinsen Attoari ved nedre Rhinen ca. 520 e.Kr., tabte danerne ikke overraskende slaget og kongen 
livet mod en frankisk armé under ledelse af Theudebert, søn til merovingerkongen Theuderic. ${ }^{18}$

I diskussionen om danernes rigsdannelse indgår en analogi til frankernes udvikling fra stammer til kongerige(r). Analogien bygger bl.a. på den nederlandske arkæolog Anthonie Heidingas analyse af elite og bebyggelse i de frankiske oprindelsesområder nord for nedre Rhinen. ${ }^{19}$ Der findes ligheder med det arkæologiske materiale i Sydskandinavien, som gør det muligt at lave en analogislutning om en udvikling fra flere små stammer, over et stammeforbund, hvor stammerne enten underlægges en ledende stammes hegemoni, eller der skabes en ny fælles stammeidentitet, og til sidst evt. dannelsen af et kongerige. Analogien betyder selvfølgelig ikke, at udviklingen fandt sted samtidig der og her. Danerne ses i kilderne århundreder efter frankerne.

Givetvis foregik interaktionen ikke med frankerne, men mellem de nogenlunde jævnbyrdige stammer (peer polities), som fandtes indenfor det sydskandinaviske kulturområde. Det fremgår med al tydelighed af både tekst og illustration..$^{20}$ Det var indenfor det sydskandinaviske kulturområde, at en proces ifølge Renfrews peer polity interaction over tid førte til dannelsen af først et hypotetisk stammeforbund under danernes ledelse og senere til et kongerige med en danerkonge. Det sydskandinaviske kulturområde bestod ifølge modellen stadig omkring 500 e.Kr. af flere forskellige stammeområder. Og det er først fra omkring 700, at danernes kongedømme begynder at træde frem. ${ }^{21}$ Så vidt jeg kan forstå, afviger RBIs opfattelse egentlig ikke så meget fra denne model med flere stammer i romersk og ældre germansk jernalder samt et kongerige in spe i yngre germansk jernalder; forskellen er, at RBI ikke tror på et stammeforbund, men hans grund til at afvise det er ikke overbevisende.

For at afvise tesen om udviklingen af stammeforbund hos de germansktalende stammer i yngre romersk jernalder henviser RBI til to historikere, Adrian Goldsworthy og Hugh Elton (s. 153-154). Teorien, at stammeforbund var et led i udviklingen af flere europæiske kongeriger, bygger på analyser fremlagt $i$ et stort værk af Reinhard Wenskus, og den er senere videreudviklet af en lang række betydningsfulde historikere. ${ }^{22}$ Selvfølgelig kan Wenskus' teser diskuteres, men RBIs henvisning til den populærvidenskabelige publikation af Goldsworthy ${ }^{23}$ leder kun til et kort referat af den amerikanske historiker Hugh Eltons diskussion om de barbariske folks militære evner. ${ }^{24}$ Den bog kan ikke overbevise mig om, at Wenskus så grundlæggende forkert på de germansktalende stammers styreformer, især da Elton slet ikke diskuterer eller nævner Wenskus. Elton fremfører i sin bog tesen, at det ikke var den romerske armés svaghed, der fik det vestromerske imperium til at bryde sammen (han fører en slags dolkestødsargumentation). Han hævder, at de germansktalende stammer kun 
havde begrænset militær styrke, og at de således ikke var en egentlig trussel for den stærke romerske krigsmagt. Han bygger sin opfattelse af de germansktalende stammer på et overfladisk og delvis forældet kendskab til arkæologi. F.eks. mener han, at "barbarerne" havde "a lack of skilled craftsmen and resources", ${ }^{25}$ hvilket viser, at han bl.a. ikke kender til eller forstår betydningen af de sydskandinaviske hærudstyrsfund.

Han mener desuden, at de barbariske samfund næppe udvikledes fra 1. til 5. århundrede, en opfattelse som det er svært at tage alvorligt. ${ }^{26}$ Som arkæolog vil jeg snarere påstå, at de barbariske samfund udvikledes meget fra ældre romersk jernalder til folkevandringstid. Forklaringen er nok, at Elton som historiker baserer sin primære opfattelse på et meget lille og problematisk kildemateriale, de romerske skriftlige kilder, og at han fokuserer på de militære konflikter mellem Imperium Romanum og barbarerne. Wenskus og andre historikere har derimod brugt de kilder, som belyser de germansktalende folks styreform, dvs. deres politiske system. ${ }^{27}$ Det arkæologiske kildemateriale fra Europa er enormt, men har alligevel store mangler. Det samlede indtryk er til trods herfor, at Elton ikke har ret, når han skriver, at "There was no significant change in barbarian [military] equipment from Tacitus' time until the sixth century". ${ }^{28}$ I hvert tilfælde var deres militære og politiske evner blevet større.

RBI mener (s. 153), at det er en selvmodsigelse, at det kun var i Sydskandinavien, at peer polity interaction medførte, at en stormagt ("Großmacht") opstod, medens det øvrige Skandinavien fortsat bestod af småkonge- og høvdingedømmer ("Kleinkönig- oder Häuptlingstümern"). Denne fremstilling af modellen er forkert. Begrebet stormagt findes ikke i den. I stedet for beskrives det af daner ledede stammeforbund som sammensat af flere småkonge- og høvdingedømmer (peer polities). Det væsentlige i et stammeforbund var stammerne og deres ledere. Et stammeforbund kunne f.eks. dannes, når én stamme opnåede et overherredømme, hvilket betyder, at denne stammes egen leder ("konge") blev overkonge; og i de andre stammer fortsatte deres småkonge/ høvding som leder. For det meste var de enkelte stammer mere eller mindre autonome; det var kun ved særlige lejligheder, at et stammeforbund trådte i funktion. Det hypotetiske stammeforbund i Sydskandinavien kan ikke beskrives som en "Großmacht", men med den opnåede hegemoni fik danerne mulighed for, indenfor stammeforbundets begrænsninger, at udøve indflydelse over store dele af det, som i dag er Sydskandinavien. Stammeforbundet danner således baggrund for den efterfølgende rigsdannelse.

At se begrebet Staatsbildung brugt om det foreslåede stammeforbund (s. 153) er både overraskende og trist. Begrebet archaic state kan med relevant definition bruges om jernaldersamfund, ${ }^{29}$ og man kan også bruge begrebet Personenver- 
bandstaat med henvisning til definitionen. ${ }^{30}$ Men man kan ikke bare bruge begrebet "stat" uden videre forklaring. Jeg er enig med Ole Fenger i, at "det ikke går an at oversætte middelalderens rige, dets kejser, konge og kirke, med vort statsbegreb, som er et begreb skabt i den såkaldte oplysningstid af jurister og siden defineret af jurister"; ${ }^{31}$ begrebet stat bør slet ikke bruges om middelalderens og tidligere tiders kongedømmer og kongeriger. Hvis man mener noget andet, må man tilbagevise Fenger med dokumenteret argumentation; at skrive uden reference, at man "rechtshistorisch" kan hævde, at "skandinavische Staaten" fandtes tidligst i det 13. århundrede er utilfredsstillende (s. 157).

Skuffende er også brugen af et begreb som "Königtum im eigentlichen Sinne” (s. 154). Hvad er det? Læseren får ingen vejledning i bogen, hvilket er forståeligt, da det er meget vanskeligt at definere begrebet kongedømme på en måde, så det er dækkende for jernalderen. ${ }^{32}$ Men man kan forsøge. ${ }^{33}$ "Rige" betyder "herredømme", "magt", først og fremmest over mennesker, og i overført betydning kan begrebet bruges om det område, de bebor, dvs. "land". ${ }^{34} \mathrm{Vi}$ bruger "rige" alene eller i sammensæetninger som "kongerige". Etymologisk betegner "konge" kun en mand, "som hører til en fornem slægt". Hvor gammelt ordet er i Danmark er vanskeligt at sige, men måske havde flere af folkevandringstidens sydskandinaviske stammer en kuning som leder. Det er ifølge Wolfram hos de frankiske merovinger, at kuning får sin middelalderlige betydning. ${ }^{35}$ Et herredømme kan have forskellig karakter: kongedømme, høvdingedømme, hertugdømme, etc. I skandinavisk jernalder kan man betragte et regionalt herredømme som et høvdingedømme eller et småkongedømme. Og et overregionalt herredømme kunne benævnes kongedømme/rige, hvis det ikke var organiseret som et oligarki. Som i et stammeforbund kunne høvdinge og småkonger fortsætte $i$ et kongerige som regionale og lokale ledere. Det er vigtigt at notere, at lederne for riger og herredømmer baserede deres magt på mennesker, og derfor er begreberne ikke oprindeligt territorielle, jf. "Personenverbandstaat".

Ifølge modellen over udviklingen fra stamme til rige i Sydskandinavien gik flere stammer/småkonge- og høvdingedømmer i løbet af yngre romersk jernalder og folkevandringstid sammen i et mere eller mindre løst organiseret stammeforbund (i begyndelsen måske to eller flere mindre forbund). Stammeforbundene kan have haft en ledelse organiseret som et overkongedømme, sandsynligvis ledet af en konge hentet fra det mægtigste af de indgående herredømmer; danerne blev den med tiden dominerende stamme. I modellen antages det, at et mere eller mindre integreret kongerige udvikledes over tid, og det træder frem i skriftlige kilder i sen yngre germansk jernalder og vikingetid. ${ }^{36}$ Rydder man misforståelserne af vejen, kan jeg derfor ikke se andet end, 
at RBI, der ser indicier for et dansk kongerige allerede tidligt i det 8. århundrede (s. 157), er enig med mig. Så egentlig kan jeg ikke se, at Ravn har ret i, at RBI "underminerer" min fremstilling af rigsdannelsen.

Jeg ser en bredere baggrund for folkevandringstidens konflikter i Skandinavien. ${ }^{37}$ De indirekte og direkte influenser fra den romerske kultur, som ses i de nordiske Sösdala- og Nydam-stile, vidner sandsynligvis bl.a. om skandinaver, som vendte hjem efter at have taget del i kampene mellem barbarer og Det romerske Rige. De yngre mænd, som i 400-tallet vendte hjem fra krigene på Kontinentet, havde erfaringer, kundskaber og guld med, hvilket kan have bragt dem i konflikt med den hjemlige elite, som baserede sin livsstil på idealer fra den romerske jernalder. ${ }^{38}$ Disse konflikter bidrog til forandringer, som senere får et materielt udtryk i den yngre germanske jernalder. ${ }^{39}$ Folkevandringstidens nye krigerelite var stærkt influeret af en international krigerkultur, som i en stor del af folkevandringstiden var domineret af goter og gepider med en markant indflydelse fra nomadiske folk, især hunnerne. I den sene folkevandringstid manifesteres kampen om magten i Sydskandinavien bl.a. gennem stærke kunstneriske udtryk som guldbrakteater og i den symbolfyldte stil I, som sandsynligvis opstod netop gennem en intens interaktion mellem gamle stammeledere og den ny elite af krigsherrer.

Den ny elite kunne i den sene fase af folkevandringstiden befæste de vundne positioner efter 400-tallets mange krige. Det kan måske bl.a. forklare, at nedlæggelser af hærudstyr ophørte i denne fase. ${ }^{40}$ Folkevandringstidens idealer blev i Skandinavien fastholdt så længe, at perioden her varede måske op til 100 år længere end på Kontinentet. ${ }^{41}$ Men snart blev et kulturelt sporskifte nødvendigt, sandsynligvis som følge af dels kollapsen i det gotiske kongeriges alliancepolitik efter kong Teoderik den stores død 526 e.Kr., dels de frankiske merovingers sejre i begyndelsen af 500-tallet under kong Klodvig og hans efterfølgere. ${ }^{42}$ Det ovenfor omtalte angreb, som en Rex Danorum rettede mod et merovingisk kongerige mellem c. 515 og 525, er et tegn på skandinavisk interesse for det frankiske område. Med det radikale kulturelle skift, som i Sverige rubriceres som Vendel-kulturen, ophørte Det romerske Rige at være idealet, og i stedet trådte det frankiske rige som forbillede, en imitatio regni Francorum.$^{43}$ Under yngre germansk jernalder forandrede folkevandringstidens krigerelite sig til markejere. ${ }^{44}$ Men det er en anden historie.

Diskussionen om processen, som førte til danernes rigsdannelse i yngre jernalder, blev ført inden for projektet "Fra stamme til stat i Danmark", et projekt RBI slet ikke nævner. Fra stamme til stat-projektet var et mangevidenskabeligt projekt med en række seminarer som arbejdsform. Her diskuteredes forudsætningerne for at studere udviklingen af jernaldersamfundenes styre- 
former. ${ }^{45}$ Et stort og varieret arkæologisk kildemateriale samt analogislutninger blev trukket ind i analyserne, hvilket fremgår af den syntese baseret på diskussionerne, som er publiceret. ${ }^{46}$ Diskussionen om begreberne stamme og stat medførte desuden erkendelsen af, at projektets navn burde have været Fra stamme til rige. Det er svært at forstå, at RBI finder det motiveret at afvise syntesen fra Fra stamme til Stat-projektet på et så spinkelt grundlag og uden ordentlig argumentation. Især misforståelserne af begreberne "stammeforbund" og peer polity interaction er belastende.

Bogen, der udkom 2010, er en udvikling af et "Magisterarbeit" ved Aarhus Universitet fra 2004, som udbyggedes til et "Doktorarbeit", forsvaret samme sted i 2008. Selvfølgelig er ansvaret for indholdet først og fremmest forfatterens eget, men en vejleder, et bedømmelsesudvalg, en projektleder og en redaktør står også inde for kvaliteten. Jeg finder det bl.a. kritisabelt, at Wenskus og efterfølgeres arbejder fejes til side så let i et akademisk arbejde, som forventes at være på et højt niveau. Måske stilles der lavere krav til en dansk ph.d. end til et tysk Doktorarbeit? Den nye Nydam-publikation ligger i hvert tilfælde på et væsentligt højere niveau både i argumentationens stringens og i dybden i referencerne til den videnskabelige diskussion. ${ }^{47}$

\section{NOTER}

1. Jf. Fabech 2006; Fabech 2009.

2. Herschend 2003; jf. Rau 2010, s. 515.

3. Näsman 2006.

4. Näsman 1994, s. $22-25$.

5. Rau 2010, s. 473-490.

6. Efter Rau 2010, s. 483 om nedlæggelsen Nydam 4.

7. Elton 2004, s. 76.

8. Jf. Fabech 1987, s. 172, et upubliceret eksamensarbejde fra Aarhus Universitet, som RBI nemt havde kunnet få adgang til.

9. Näsman 1999, s. 5-6 versus Näsman 1997, s. 57-58.

10. Wood 1983, s. 18-19.

11. Näsman 1994, fig. 8; fig. 4 i Kuml 2006, s. 220.

12. Jørgensen \& Jørgensen 1997, s. 115.

13. Jf. Storgaard 2001; i RBIs rimelige kritik af Storgaards artikel mangler desværre den s. 139 i note 161 nævnte reference i bogens Literaturverzeichnis; skal være anmeldelsen i Kuml 2002, s. 353-357.

14. Jf. at begrebet Regnum Francorum (frankernes rige) først sent erstattedes med Regnum Franciae (det frankiske rige), Wolfram 1971, s. 8 note 34 .

15. Begrebet Rex (konge) er sikkert bevidst appliceret af Gregor af Tours på danernes hærfører, se Wood 1983, s. 6.

16. Renfrew 1986; Näsman 1998.

17. Jf. hvordan begrebet bruges af Rau 2010, s. 515-518. 
18. Wood 1983, s. 6-7.

19. Heidinga 1990.

20. Fig. 6a i Kuml 2006, s. 224.

21. Fig. 6b i Kuml 2006, s. 225.

22. Wenskus 1961/1977.

23. Goldsworthy 2000, s. 180.

24. Elton 1997/2004.

25. Elton 2004, s. 57.

26. Elton 2004, s. 43.

27. Jf. et par klassiske studier, Schlesinger1953/1956/1968; Schlesinger 1956; Wolfram 1971.

28. Elton 2004, s. 72.

29. Se f.eks. Rau 2010, s. 490-491.

30. Se f.eks. Rau 2010, s. 516.

31. Fenger 1991, s. 294; jf. Näsman 1997, s. 50.

32. Jf. et stadig både relevant og interessant studie af folkevandringstidens kongemagt på kontinentet i Wolfram 1971.

33. Her modificeret efter Näsman 1997, s. 50 med ref. til N.Å. Nielsen 1989/1966.

34. Jeg er derfor ikke enig med Rau 2010, s. 491, som synes at mene, at "rige" er et anakronistisk begreb, hvis det bruges om jernaldersamfund.

35. Wolfram 1971, s. 6.

36. Se fig. 7 i Kuml 2006.

37. Disse tanker bygger på mine og Charlotte Fabechs studier i projektet "Mellan svear och daner - Om samhällens förändring i perioden 200 till 700 e.Kr." finansieret af Vetenskapsrådet i Sverige.

38. Olausson 2009; Fabech 2011, s. 34.

39. RBI anser (s. 157), at nye våbentyper i yngre germansk jernalder spejler en ny type af erobringskrig. Jeg ser dem mere som resultat af forandringer i europæisk våbenproduktion og -handel efter den romerske industris forfald i det 5. århundrede og før den karolingiske oprustning fra sent i det 8 . århundrede til ind i vikingetid. Jeg kan heller ikke følge hans ræsonnement, at simple våben er lig med større hære, er lig med erobringskrig, er lig med rigsdannelse.

40. Jf. Rau 2010, s. 483-488.

41. Kristoffersen \& Magnus 2010, fig. 20; Rau 2010, Abb. 41.

42. Jf. Halsall 2007, s. 284-310.

43. Näsman 1991, s. 174 med henvisninger.

44. Jf. Herschend 2009, s. 405. Se dog Wickham 2005, s. 373, som forkaster tanken om et jordejende aristokrati i Danmark før det 11. århundrede.

45. Mortensen \& Rasmussen (red.) 1988; Mortensen \& Rasmussen (red.) 1991.

46. Näsman 1988; Näsman 1991; Näsman 1997; Näsman 1998; Näsman 1999; Näsman 2006.

47. Alligevel er det godt, at tidligere studerende viser sund skepsis til både autoriteter og etablerede opfattelser, også de som stammer fra deres egen lærer. Det adskiller sig positivt fra den tribalism, som præger meget dansk arkæologi med ukritisk accept af den egne stammes teser (jf. Herschend 2011 med morsom jævnførelse af en formodet social struktur i romersk jernalder på Sjælland med et nutidigt socialt hierarki inden for østdansk arkæologi). 


\section{LITTERATUR}

Elton, H. 2004 (1st ed. 1997): Warfare in Roman Europe AD 350-425. Oxford.

Fabech, C. 1987: Krigsbytteoffer religiøs ceremoni eller politisk manifestation. Aarhus (upubliceret magisterafhandling, Aarhus Universitet).

Fabech, C. 2006: Centrality in Old Norse mental landscapes. I: A. Andrén, K. Jennbert \& C. Raudvere (red.): Old Norse religion in long-term perspective. Lund, s. 26-32.

Fabech, C. 2009: Fra ritualiseret tradition til institutionaliserede ritualer. I: A. Carlie (red.): Järnålderns rituella platser. Halmstad, s. 317-342.

Fabech, C. 2011: War and rituals. Changes in ritual and transformations of power. I: T.A.S.M. Panhuysen (red.): Transformations in North-Western Europe (AD 300-1000). Hannover, s. 27-36.

Goldsworthy, A. 2000: Roman warfare. London.

Halsall, G. 2007: Barbarian migrations and the Roman West 376-568. Cambridge.

Heidinga, H.A. 1990: From Kootwijk to Rhenen: in search of the elite in the Central Netherlands in the Early Middle Ages. I: J. Besteman et al. (red.): Medieval archaeology in the Netherlands. Studies presented to H.H. van Regteren Altena. Amsterdam, s. 9-40.

Herschend, F. 2003: Krig, offerfynd och samhälle i 200-talets Sydskandinavien. Fornvännen 98, 2003/4, s. 312-316.

Herschend, F. 2009: The Early Iron Age in South Scandinavia. Social order in settlement and landscape. Uppsala.

Herschend, F. 2011: In death we trust. Society as burial order. http://floasche.wordpress. com/2011/08/22/in-death-we-trust-society-as-burial-order/

Jørgensen, L. \& A. Nørgård Jørgensen 1997: Nørre Sandegård Vest. A cemetery from the 6th-8th centuries on Bornholm. København. Sammenfatning.

Kristoffersen, S. \& B. Magnus 2010: Spannformete kar. Udvikling og variasjon. Stavanger. Summary.

Mortensen, P. \& B.M. Rasmussen (red.) 1988: Fra Stamme til Stat i Danmark. 1 Jernalderens samfund. Højbjerg. Summaries.

Mortensen, P. \& B.M. Rasmussen (red.) 1991: Fra Stamme til Stat i Danmark. 2 Høvdingestammesamfund og kongemagt. Højbjerg. Summaries.

Nielsen, N.Å. 1989 (1. udg. 1966): Ordenes historie. Dansk etymologisk ordbog. København.

Näsman, U. 1988: Analogislutning i nordisk jernalderarkæologi. I: P. Mortensen \& B. M. Rasmussen (red.): Fra Stamme til Stat i Danmark. 1 Jernalderens stammesamfund. Højbjerg/ Århus, s. 123-140. Summary.

Näsman, U. 1991: Det syvende århundrede. I: P. Mortensen \& B.M. Rasmussen (red.): Fra Stamme til Stat i Danmark. 2 Høvdingesamfund og kongemagt. Højbjerg, s. 165-177. Summary.

Näsman, U. 1994: The Iron Age Graves of Öland - Representative of What? I: B. Stjernquist (red.): Prehistoric Graves as a Source of Information. Stockholm, s. 15-30.

Näsman, U. 1997: Från region till rike - från stam till stat. I: F. Krøger (red.): Rikssamlingen, høvdingmakt og kongemakt. Karmøy, s. 46-65, refs. s. 110-114.

Näsman, U. 1998: Sydskandinavisk samhällsstruktur i ljuset av merovingisk och anglosaxisk analogi eller i vad är det som centralplatserna är centrala? I: L. Larsson \& B. Hårdh (red.): Centrala platser. Centrala frågor. Samhällsstrukturen under järnåldern. Lund, s. 1-26.

Näsman, U. 1999: The ethnogenesis of the Danes and the making of a Danish kingdom. I: T. Dickinson \& D. Griffiths (red.): The making of kingdoms. Oxford, Anglo-Saxon Studies in Archaeology and History 10, s. 1-10. 
Näsman, U. 2002. Anmeldelse af Birger Storgaard (red.): Military aspects of the aristocracy in Barbaricum in the Roman and Early Migration periods. København 2001. Kuml 2002, s. 353-357.

Näsman, U. 2006: Danerne og det danske kongeriges opkomst. Kuml, s. 205-241. Summary.

Olausson, M. 2009: At peace with walls - Fortifications and their significance AD 4001100. I: L. Holmquist-Olausson \& M. Olausson (red.): The martial society. Aspects of warriors, fortifications and social change in Scandinavia. Stockholm, s. 35-70.

Rau, A. 2010: Nydam Mose 1-2. Die personengebundenen Gegenstände. Grabungen 1989-1999. Højbjerg. Summary. Dansk resumé.

Renfrew, C. 1986: Introduction. I: C. Renfrew \& J. Cherry (red.): Peer Polity Interaction and Socio-political Change. Cambridge, s. 1-18.

Schlesinger, W. 1953: Herrschaft und Gefolgschaft in der germanisch-deutschen Verfassungsgeschichte. Historische Zeitschrift 176, s. 225-275. - Også s. 9-52 i Schlesinger, W. 1963: Beiträge zur deutschen Verfassungsgeschichte des Mittelalters 1. Germanen, Franken, Deutsche. Göttingen. - Noget afkortet udg. på engelsk, se Schlesinger, W. 1968: Lord and follower in Germanic institutional history. I: F.L. Cheyette (red.): Lordship and community in Medieval Europe. New York, s. 64-99.

Schlesinger, W. 1956: Über germanisches Heerkönigtum. I: Das Königtum. Lindau/Konstanz: Thorbecke, s. 105141. 4. opl. 1973. Også i Schlesinger 1963, se ovenfor, s. 53-87.

Storgaard, B. 2001: Himlingøie - barbarian empire or Roman implantation? I: B. Storgaard (red.): Military aspects of the aristocracy in Barbaricum in the Roman and Early Migration periods. København, s. 95-111.

Wenskus, R. 1961 (2. udg. 1977): Stammesbildung und Verfassung. Köln.

Wickham, C. 2005: Framing the Early Middle Ages. Europe and the Mediterranean 400-800. Oxford.

Wolfram, H. 1971: The shaping of the early medieval kingdom. Viator 1, 1970, s. 1-20.

Wood, I. 1983: The Merovingian North Sea. Alingsås. 